\title{
STEAM-Project-Based Learning Integration to Improve Elementary School Students' Scientific Literacy on Alternative Energy Learning
}

\author{
Adriyawati $^{1}$, Erry Utomo ${ }^{1}$, Yuli Rahmawati ${ }^{2, *}$, Alin Mardiah $^{2}$ \\ ${ }^{1}$ School of Basic Education, Universitas Negeri Jakarta, Indonesia \\ ${ }^{2}$ Department of Chemistry Education, Universitas Negeri Jakarta, Indonesia \\ Received February 7, 2020; Revised April 2, 2020; Accepted April 19, 2020
}

Copyright $\mathrm{C} 2020$ by authors, all rights reserved. Authors agree that this article remains permanently open access under the terms of the Creative Commons Attribution License 4.0 International License

\begin{abstract}
The study aimed to find out how the integration of STEAM-Project-Based Learning (STEAM-PjBL) was applied with the aim of developing students' scientific literacy. The study employed a qualitative research method with multiple data collection through interviews, observations, reflective journals, and a scientific literacy test. The integration of STEAM-PjBL was applied in a science classroom at a public elementary school in West Java, Indonesia with the thirty grade 4 students. The study consisted of five steps of reflection, research, discovery, application, and communication (Laboy-Rush, 2010). A house miniature with hand-powered electric generator or solar-powered generator is employed as STEAM project on alternative energy learning topic. The collected data was analysed using five aspects of scientific literacy, namely general scientific ideas, science characteristic, natural science in context, higher-order thinking skills, and affective aspect. The results of scientific literacy analysis show that overall the highest percentage has reached the level of competence Integration of STEAM-PjBL into science learning encouraged students to be able to see the relevance of science knowledge of phenomena in daily life, develop curiosity and problem solving, and increase students' courage to ask questions and explore various sources to find information. The challenges faced during the research are source and time management, development of project ideas according to the topic of learning, and student involvement in learning. In addition, students also get meaningful and interesting learning by STEAM project making. This research also provides an opportunity for teachers to develop their competence in applying various learning models.
\end{abstract}

Keywords Elementary School Students, Scientific Literacy, STEAM-PjBL, Science Learning, Alternative Energy

\section{Introduction}

Science learning at the elementary school level is a subject that is expected to be a media for students to study the natural surroundings and prospects for further development in daily life. Thus, science is not just a collection of theories in the form of concepts and facts but also a process of discovery. This requires a creative thought processing to learn many abstract concepts as well as a scientific process that requires experimental activities to support learning, so as to develop students' level of understanding. An understanding of scientific concepts and scientific facts is the goal of scientific literacy (Ajayi, 2018). According to Chen, (2019), reconceptualization of scientific literacy is a demand that students are not only able to read, write and speak scientific texts, but also have the ability to analyze, interpret, and make a reason in the discourse of science. Bauer and Booth (2019) stated that the ability of scientific literacy is expected that students are able to detect and identify social problems as well as solutions to problems that students face. Furthermore, the development of scientific literacy needs to be done so students can discuss scientific issues that have an impact on students' technology and culture (Sahin \& Deniz, 2016; Roach, 2018).

Students with good scientific literacy skills must have broader skills, namely the ability to ask questions that are useful for finding information to answer questions, so students who are literated in science have a realistic perspective on science (Shwartz, Ben-Zvi, \& Hofstein, 2006). Davies et al. (2013) states that knowledge formed through learning science supports the literacy of students involved in practice. The position of scientific literacy as a combination of various practices and skills using the 
process of doing, producing, and developing scientific understanding (Buchholz \& Pyles, 2018). Thus, the education sector is currently required to be able to develop scientific literacy so that students are able to make effective knowledge-based decisions and able to apply the concepts of knowledge they learn to solve problems that occur in real life (UNESCO, 2005; Murcia, 2007; National Research Council (NRC), 2012). One comprehensive survey assessing the achievement of scientific literacy internationally is the PISA (Program for International Student Assessment). PISA survey results in 2018 showed that the level of achievement of scientific literacy of Indonesian students is still low; Indonesia ranked 72 out of 77 countries (OECD, 2019).

Some factors that may cause the low scientific literacy of Indonesian students are students not accustomed to being given questions in the form of discourse and learning processes that do not support the development of student literacy (Siagian, Silitonga, \& Djulia, 2017). Conventional learning that has been applied for a long time in Indonesia makes students difficult in opinion, so it limits the development of students' critical thinking skills. Recently, the task of the teacher is not only to transmit knowledge, but also to be able to reflect on themselves and apply various learning methods which support students to develop the required skills (Rahmawati \& Taylor, 2015).

One of learning approaches that can be applied to overcome the problem description is the Science, Technology, Engineering, and Mathematics (STEM) approach. The STEM approach which later developed into STEAM which is applied in science learning provides opportunities for students to be able to develop scientific literacy. Research on the integration of STEAM in learning has been widely carried out in Indonesia and has a variety of implications, including research conducted by (Ridwan, Rahmawati, \& Hadinugrahaningsih, 2017) showing that the STEAM approach can develop higher-order thinking skills, collaboration, argumentation, and creativity in participants students. The results of the study (Afriana, Permanasari \& Fitriani, 2016) revealed that STEM integrated Project Based Learning (PjBL) can increase student interest in learning, develop scientific literacy, and give students the opportunity to solve problems in real life and support future careers. The results of the study meet the indicators of one aspect of scientific literacy proposed by (Shwartz, Ben-Zvi, \& Hofstein, 2006), namely high-level learning abilities. Therefore, the STEAM approach can be applied in learning to improve scientific literacy in students.

Science learning in accordance with the STEAM approach can be done with the PjBL (Project Based Learning) learning model. The PjBL learning model emphasizes contextual learning through complex activities such as giving students freedom to explore and plan learning activities, carry out collaborative projects, and ultimately produce a product (Rais, 2010). Chen and Yang (2019) state that in project-based learning students learn through projects to get the actual product. In addition, the teacher also oversees the project making process to ensure that each student is actively involved in carrying out the project activities. The role of the teacher is very important in learning topics where students learn to carry out research projects and design an innovative work (Vossen, et. al., 2019). The PjBL integrated STEAM approach is carried out with learning that produces a product by applying the STEAM principles (Science, Technology, Engineering, Arts, and Mathematics) in making projects.

The topic of Energy is one of the topics of science learning at the elementary school level in the 2013 curriculum. Çoker, Çatlioğlu, and Birgin (2010) state that energy is a scientific concept that has wide application in life because it occurs in various forms, such as light, sound, electromagnetic, heat, potential, gravitational and kinetic energy and it can be transformed into alternative forms of energy needed by humans. Energy is an effort or force carried out in daily life and it has an effect that can be observed by students. Current energy infrastructure is unsustainable due to a high dependence on fossil fuels, highlighting the need to develop sustainable energy (Yüksel, 2019). Thus, it is important for elementary school students to learn about renewable energy sources. Therefore, this topic is important to help students to understand the concept of energy and the need for environmental sustainability. Thus, the development of scientific literacy on the concept of energy needs to be done, which is in view of the diminishing availability of energy (Merritt, Bowers, \& Rimm-Kaufman, 2019).

In preliminary research in SD Negeri Aren Jaya XVIII shows the value of the national standard school examinations 2018/2019 academic year in science subjects, only $1 \%$ of the number of students scored in the range of $90-99$ and $65 \%$ in the range of grades $80-90$, as many as $34 \%$ received the lowest score below the minimum completeness criteria. Classroom observation results show that there are still many students who have not been able to describe scientific ideas about alternative energy correctly and how to save energy. Based on the description above, the researchers are interested in applying the STEAM-PjBL learning model in science learning to the topic of energy as a solution to develop scientific literacy so students are able to analyze and understand ways of producing and saving energy used in everyday life. 


\section{Research Methodology}

The aim of study was to analyze how the integration of STEAM-PjBL into science learning develops students' scientific literacy. The study employed a qualitative method with multiple data collection of reflective journal, classroom observations, interviews, and a scientific literacy test on alternative energy topic. The study was held ten times across a five weeks period. The study consists of three stages of preliminary stage, the implementation stage, and the final stage. While the integration of STEAM-PjBL was implemented through five stages of learning, namely reflection, research, discovery, application, and communication (Laboy-Rush, 2010) as seen as the following figure 1.

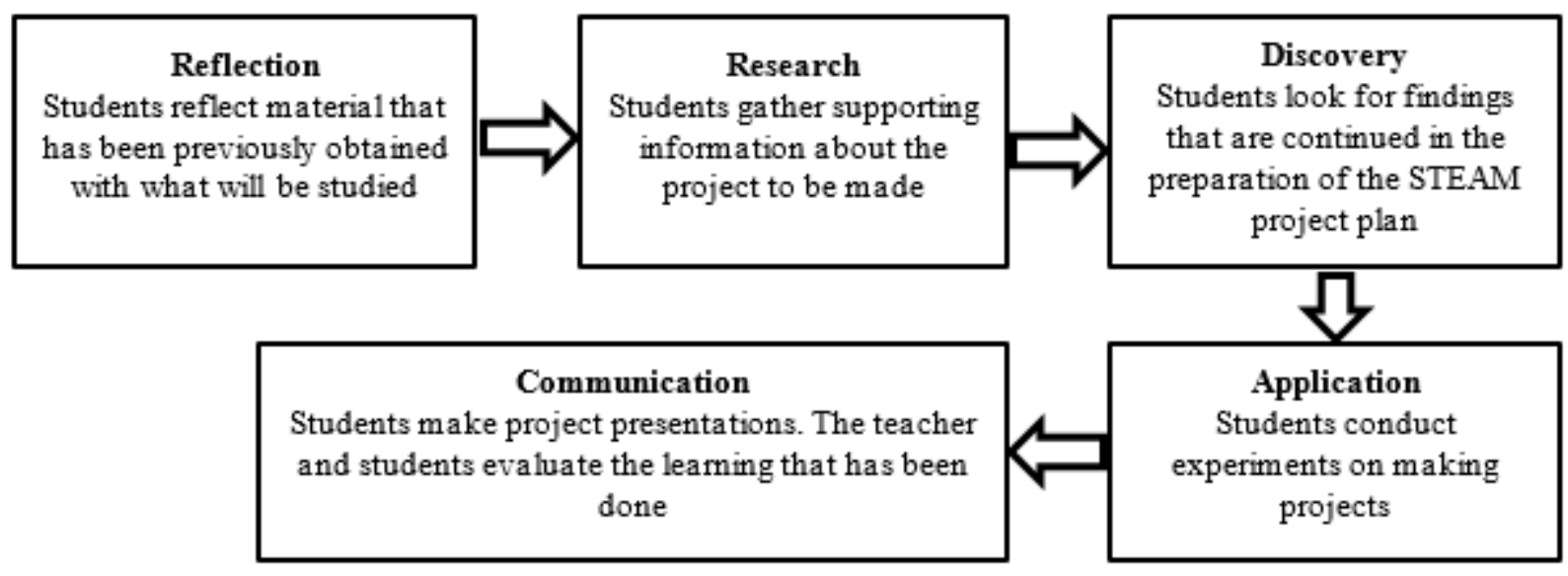

Figure 1. Learning Steps of STEAM-PjBL

\subsection{Participants}

The study involved the thirty grade 4 students consisted of 18 male and 12 female students at a public elementary school in West Java, Indonesia.

\subsection{Data Collection}

The study was conducted in three stages, namely preliminary, implementation, and final stage. In the preliminary stage, researchers conducted initial research by conducting semi-structured interviews with teachers and students to determine students' motivation and academic abilities as research subjects. In addition, researchers formulate a scheme of work by adapting the STEAM-PjBL by learning scheme (Laboy-Rush, 2010) and compile research instruments, such as STEAM project assessment guides and rubrics, compilation of scientific literacy test questions, observation guides, reflective questions of student journals, and compiling student interview questions to obtain information regarding the application of STEAM-PjBL integration learning and the development of students' scientific literacy. In the implementation phase, the researchers carried out learning, students are divided into five groups with six students in each group and each group was given the opportunity to determine the group leader. Researchers guide students in determining the product, work steps, time of making, making reports, and presentations. Whereas in the final stage, researchers reduce, analyze, interpret, and draw conclusions based on data collected through field notes, reflective journals, semi-structured interviews, and scientific literacy tests.
Reflective journals were written by students at the end of the learning exercise. Field notes were taken via direct observation of the students participating in the learning activities. The interviews took an average of 10 minutes using open-ended question with the aim to get the information on students' feeling, thinking, and their experience in relation to the integration of STEAM-PjBL and students' scientific literacy development. In addition, students completed a 90-minute science literacy test at the end of the project activity. The test was designed to assess the students' scientific literacy on alternative energy topic.

\subsection{Data Analysis}

Data analysis in qualitative research is carried out continuously until finished, so that the data is already saturated (Miles \& Huberman, 1992). Data analysis was carried out through three stages, namely data reduction, data presentation, verification and conclusions. Data reduction is the selection of important data with the aim to simplify the rough data obtained from the field. The research data was analyzed and coded by grouping nodes, selecting, focusing, and deleting unnecessary data based on five categories of science literacy by (Shwartz, Ben-Zvi, \& Hofstein, 2006). The next step after reducing the data is to present in the form of graphics, images, and narrative text. The third step in qualitative analysis according to (Miles \& Huberman, 1992) is verification and conclusions. The results of the data that have been reduced and presented conclusions are made andt will not change again. It is verified to be adjusted with valid and consistent evidence in order to obtain credible conclusions. The conclusion is 
drawn with the aim to determine students' scientific literacy development.

\section{Results and Discussions}

\subsection{The Integration of STEAM-PjBL into Science Learning}

The integration of STEAM-PjBL was implemented through five steps of learning adapted from (Laboy-Rush, 2010), namely reflection, research, discovery, application, and communication.

\subsubsection{Reflection}

The purpose of reflection stage is to bring students into the context of the problem and inspire students to begin investigating immediately. This stage also intended to link what is known and what needs to be learned by students (Laboy-Rush, 2010). In this study, the teacher stimulates students to reflect on the topic of energy by giving a number of fundamental questions that are relevant to students' daily lives. This is expected to be able to motivate students to be actively involved in learning and increase their curiosity. To attract students' interest, in the following figure 2 shows the teacher conveys learning material using video and picture media to make it easier for students to understand alternative energy as a whole with discussion and question and answer activities to examine the scientific context.
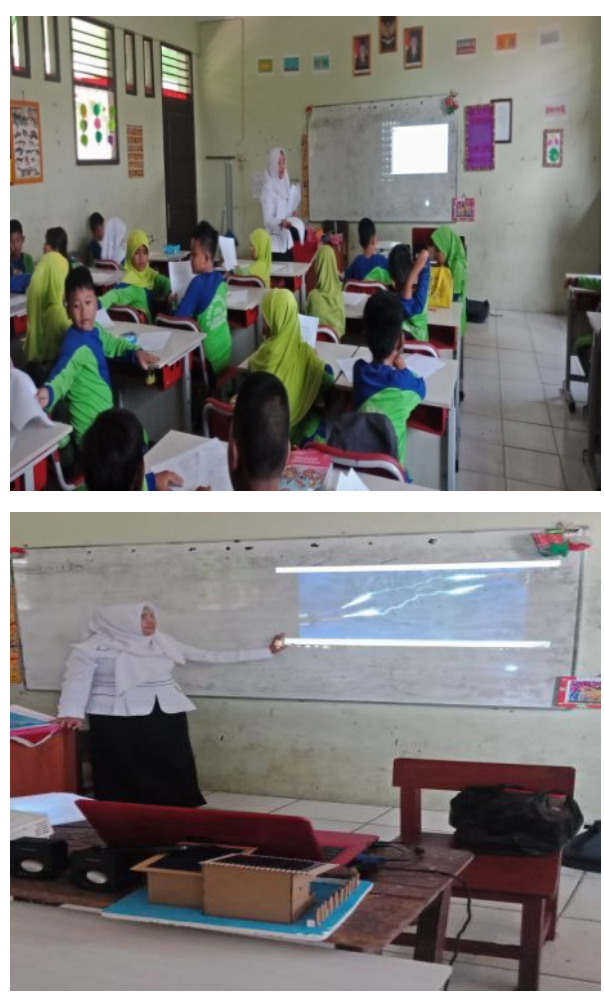

Figure 2. The Teacher Introduces the STEAM-PjBL approach in Energy Learning
At first the students seemed confused because the implementation of STEAM approach was the first time for them, when they saw the teaching aids described by the researchers, the students seemed enthusiastic and asked many questions about alternative energy, solar panels, and simple power plants, they were very interested in the project activities. The STEAM project development plan is carried out in groups consisting of 6 people for each group and chaired by one of the student selected in the group leader voting, the teacher and observer help to form the group.

\subsubsection{Research}

At this stage, students are given activities in the form of tasks regarding information and discussion related to learning material to support the project activities that will be carried out. In this stage the teacher's role is to guide and direct students to take sources of correct and relevant information that includes a collection of facts, definitions, concepts, and scientific theories related to the material.

The second stage is the form of student research. The teacher provides science learning, chooses readings, or other methods to gather relevant information sources. The learning process takes place more during this stage, the progress of learning of students concretizes an abstract understanding of the problem. During the research phase, teachers more often guide the discussion to determine whether students have developed conceptual and relevant understanding based on the project.

In this study, the teacher guides students in learning science, collects information related to science, technology, engineering, arts and mathematics (STEAM), discusses about electrical circuits and determines STEAM projects. In designing the project implementation and product determination stage, the teacher gives challenging questions about the process of work steps, several times students ask about the work steps with the suitability of the product they choose. The students understand the working principle and STEAM project work steps then they determine the STEAM product they will make up, group 1 and 2 decided to make solar panel power plants, while group 3,4, and 5 decided to make hand power plant. This stage presents its own challenges for students to creatively apply knowledge about science into real problems in everyday life.

The observations showed that students listened to the lessons delivered at the first few meetings well and gave a positive response to the learning activities provided. This can be seen from how they pay attention to the teacher's presentation and the interactions between the teacher and students by asking questions about matters related to learning topics. Exposure of material through power point media facilitates students' scientific literacy skills; it is known that students are able to mention renewable energy names. 
"What kind of energy that can be used as an alternative power plant?

Solar, wind and water energy"

(Reflective Journal of Students 17 and 30, 19 August 2019)

"Mention examples of power generation devices from alternative energy?

Windmills, water dams, and solar panels",

(Reflective Journal of Student 28, 19 August 2019)

\subsubsection{Discovery}

This stage aims to bridge the research and information that is known with project planning. Learners are entitled to the learning process and identify information that is still unknown. Some STEM project models divide students into small groups to provide solutions to problems, to collaborate and cooperate with other members in the group.

In this study, the teacher guides students in developing project schedules and work steps, before the teacher reviews the learning at the previous meeting. Through the video media the teacher gives sample material examples of hydroelectric, geothermal, wind energy, each of which is studied by students by viewing the dam video as one of the hydroelectric power plants, windmills on the wind power plant, PT Sevron video as the generator geothermal electricity and several other videos to support students' understanding of alternative energy. Through the instructional tool made by the teacher, students are introduced to the coil's reaction to the magnet which causes the attractive force of the magnet that generates electricity. The teacher explained how the process of absorbing solar thermal energy in solar panels through a photovoltaic system that converts solar energy into electric current. In solar panels there are n-type and p-type silicomes used to form an electric field. The semi-conductor moving from the n-type will form a positive pole and the semi-conductor of the p-type will instead form a negative pole. Some students ask to repeat the explanation by showing a battery and then examine the positive and negative poles of the battery.

"What difficulties do you feel in making alternative energy projects?

Sometimes I find it difficult to think how a magnetic field can produce electricity"

(Reflective Journal of Students 20, 19 August 2019)

"What do you think of project-based learning?

With the help of group member, I was able to discuss in determining the steps of making projects in various ways"

\section{(Reflective Student Journal 18, August 19, 2019)}

The teacher provides enrichment material to respond to the difficulties; students understand the concept of renewable energy that occurs in hydroelectric power plants, solar, solar, steam, geothermal, wind. Some students have been able to answer correctly, only a few pointed out small mistakes such as mistakes in writing concepts, and elements of petroleum and alternative energy. The meeting ended with an introduction to the STEAM project and the teacher gave an assignment to explore alternative energy that would be created by students. The teacher facilitates students to find out and think further about the completeness of the experimental procedure in making the STEAM product that they have specified.

The next stage students write the draft work steps on the worksheets provided. Group 4 writes the tools and materials needed such as magnets, coil wire, used CDs, markers, containers, solar panels, boards, used cardboard, rubber bands and other accessories. Students write the steps of work even though not perfect; this stage provides a challenge for students to know that electricity can be created with a simple scale. Other groups also prepare the same thing. STEAM project making is carried out in four stages, namely designing, preparing the material, project making, and presentation.

\subsubsection{Application}

At the application stage the aim is to test the product / solution in solving problems. In some cases, students test products made from predetermined provisions, the results obtained are used to improve the previous step. At this stage, students learn a broader context outside of STEAM or link between STEAM disciplines.

The implementation phase of the project of making hand power and solar power generation products is a real experimental process. Students can apply and examine why electrical energy is created, this activity also greatly motivates students to face difficulties and make them think creatively about alternative energy and use their initial knowledge to solve problems. This is evidenced by the following conversation quote.

\section{Quotation 1 \\ Student 9: Ma'am, may I look for other materials to replace coil and magnet? \\ Teacher: Of course you can, what is your idea for a substitute? \\ Student 9: Ma'am, I have a used fan, my father said there are south and north poles as you explained about coil and magnet winding, can it be used? \\ Teacher: Of course it can be used, we still use the coil to change the coil in the fan to produce DC \\ Student 9: Wow, I'm really interested, ma'am, and want to know if a fan can actually generate electricity \\ Teacher: Let's try it!}

The results indicated that STEAM learning in the project making stimulates the students' ability to discover new things. This shows that the integration of STEAM-PjBL encourages students' critical thinking in finding new general scientific ideas (Rahmawati, Ridwan, Hadinugrahaningsih, \& Soeprijanto, 2019). 

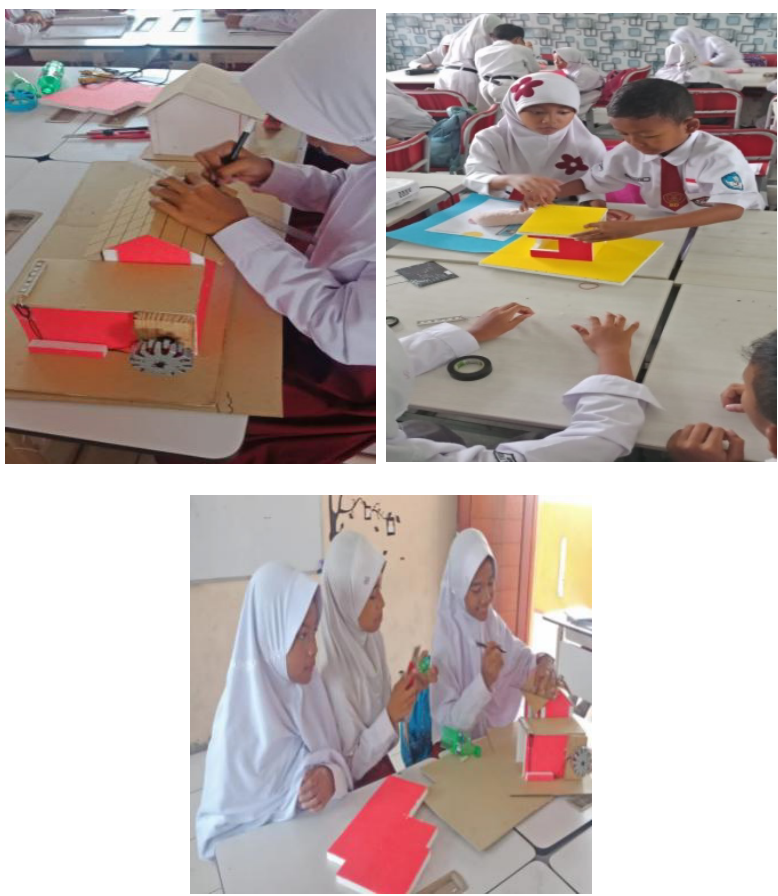

Figure 3. Students are enthusiastic in project making activity

"I learned to assemble devices using cables. I understand how solar panels can produce electricity, but I don't understand how to make solar panels, when I grow up I want to try making it"

(Reflective Journal of Student 29, 10 September 2019)

"I learned about the magnetic poles that produce force, the greater the force of attraction between the magnetic poles, the greater the electric current generated. I also study copper coil as an electrical conductor where electric current interacts with magnets. But when trying to bend a coil I need the help of a teacher, because I still don't dare to use the tool"

(Reflective Journal of Student 21, 16 September 2019)
In the figure 3 above, it can be seen that students seem enthusiastic in project activities Alternative energy learning materials are very related to technology and techniques. So this STEAM project can arouse students' curiosity about something behind the phenomenon that occurs. Moving on from interest, dissatisfaction with the results obtained, curiosity to try something else brings students to be interested in exploring deeper.
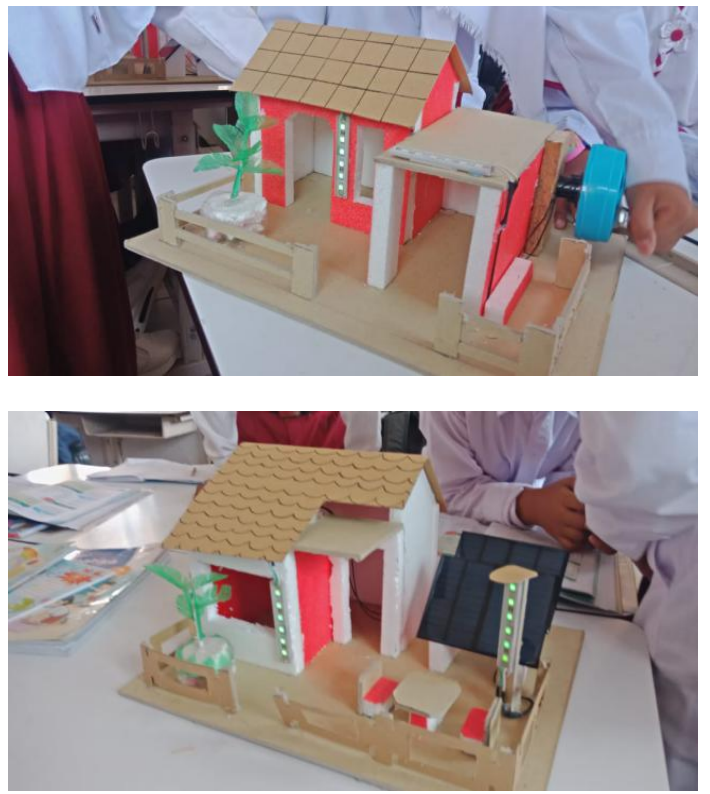

Figure 4. STEAM Project for Hand and Solar Power Plants Made by Students

The project made by students in learning activities as seen in figure 4 already meet the STEAM criteria. Students have learned to make products with appropriate techniques, correct calculations, and use their creativity to add artistic value to the product. Learning activities undertaken make students enthusiastic about learning, which is because students can produce a product based on collaboration between group members. The STEAM integration into the project that has been made is as follows:

Table 1. STEAM Integration on Hand and Solar Power Plants Project

\begin{tabular}{|c|c|c|c|c|}
\hline Science & Technology & Engineering & Art & Mathematics \\
\hline \multirow{2}{*}{$\begin{array}{c}\text { The concept of } \\
\text { alternative energy }\end{array}$} & Making a hand and & Tools design making & $\begin{array}{c}\text { Decorate the product } \\
\text { based on students' } \\
\text { creativity }\end{array}$ & $\begin{array}{c}\text { Time calculations in } \\
\text { making tools }\end{array}$ \\
\cline { 1 - 4 } $\begin{array}{c}\text { The concept of } \\
\text { electricity Learning }\end{array}$ & \begin{tabular}{c} 
technology \\
\cline { 3 - 5 }
\end{tabular} & $\begin{array}{c}\text { Connect the appropriate } \\
\text { electrical circuit to turn on } \\
\text { the LED }\end{array}$ & $\begin{array}{c}\text { Making a home } \\
\text { miniature }\end{array}$ & $\begin{array}{c}\text { Mathematical concepts to } \\
\text { find the right size for each } \\
\text { required field }\end{array}$ \\
\hline
\end{tabular}

Table 2. Student Project Assessment Results

\begin{tabular}{|c|c|c|c|c|c|}
\hline Group Name & Planning & STEAM Product Results & Report & Total Score & Assessment Criteria \\
\hline Group 1 & 25 & 40 & 25 & 90 & Very Good \\
\hline Group 2 & 20 & 35 & 25 & 80 & Good \\
\hline Group 3 & 20 & 35 & 20 & 75 & Good \\
\hline Group 4 & 25 & 40 & 23 & 88 & Very Good \\
\hline Group 5 & 20 & 35 & 28 & 78 & Good \\
\hline
\end{tabular}


Then, projects that have been made by students are assessed using the assessment rubric. The student project assessment rubric is divided into three dimensions, namely planning, STEAM product results, and reports.

Assessment results show that the average value of the product obtained by students is classified as good categories. This is because the students have successfully completed making the product according to the design, fulfilling the STEAM components, and have a clear linkage to the concepts of electricity and energy.

\subsubsection{Communication}

The communication stage is the final stage and the stage that has an important role in the learning process (Laboy-Rush, 2010). This stage provides the opportunity for students to present both project results and observations. Presentation is an important step in the learning process to develop communication and collaboration skills as well as the ability to accept and apply the views of others. Figure 5 below shows the students' presentation activities about the alternative energy project they have made.
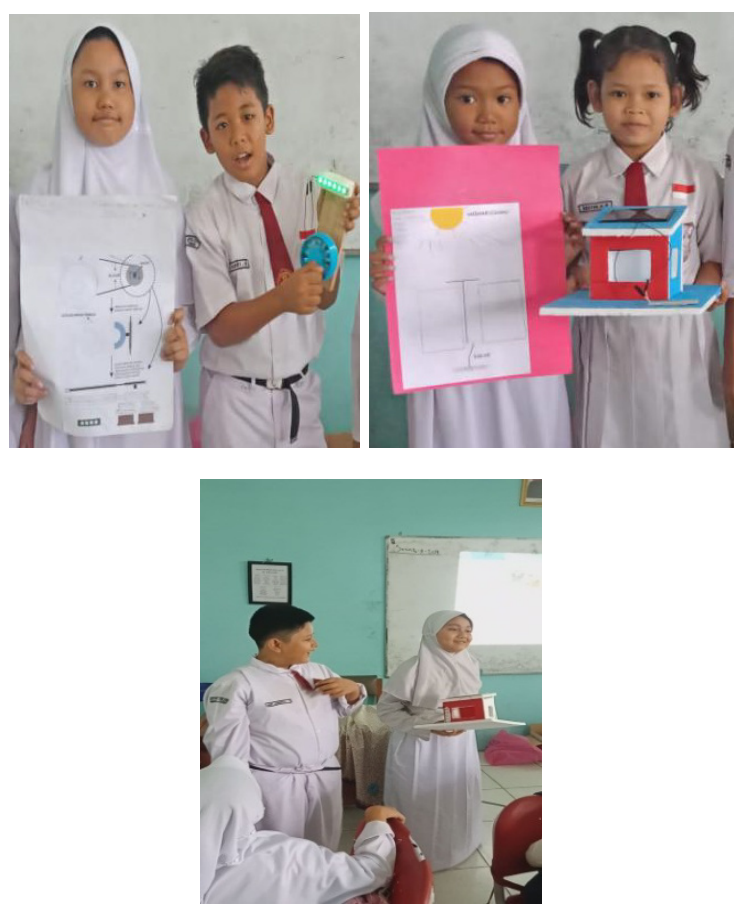

Figure 5. Students Presentation of STEAM Project
"I learned how to sketch a solar panel house, I can assemble the electrical wires and I put the solar panel separate from the house unlike what my teacher practiced, I saw it on YouTube that a number of solar panels are placed beside the house"

(Reflective Journal of Student 6, 24 September 2019)

"I made solar panels that were connected to mobile phones, my father bought additional materials as an energy storage device, and we were successful"

(Reflective Journal of Student 2, 18 September 2019)

This is in accordance with the reference that transdisciplinary in project-based learning will lead students to have a deeper understanding and enable them to solve complex problems in real life (Chen \& Yang, 2019). Students can learn to collaborate with interdisciplinary teaching strategies, have curiosity through learning STEAM based projects. When students are involved in learning, students are better able to develop skills and knowledge to reach the highest potential of students (Yamamoto \& Houghton, 2011). Furthermore, Taylor (2016) argues that STEAM education aims to build students who are creative, ethical and smart and become communicative designers in making decisions. The value of creativity and art based on STEAM learning enhances students' skills in creative-cognitive thinking so that there are no subject learning boundaries but merges into one complementarity between disciplines.

\subsection{The Analysis of Students' Scientific Literacy Development}

Students' scientific literacy was observed by the researchers using the five criterias by Shwartz, Ben-Zvi, and Hofstein (2006). The development of students 'scientific literacy skills was assessed by the ability of students to think scientifically using appropriate ideas about energy and to apply the concepts to daily life. The literacy test was developed to assess the conceptual understanding of energy in contexts related to everyday problems and the environment to stimulate higher-order thinking skills. The overall achievement level of scientific literacy is shown as the figure 6 below. 


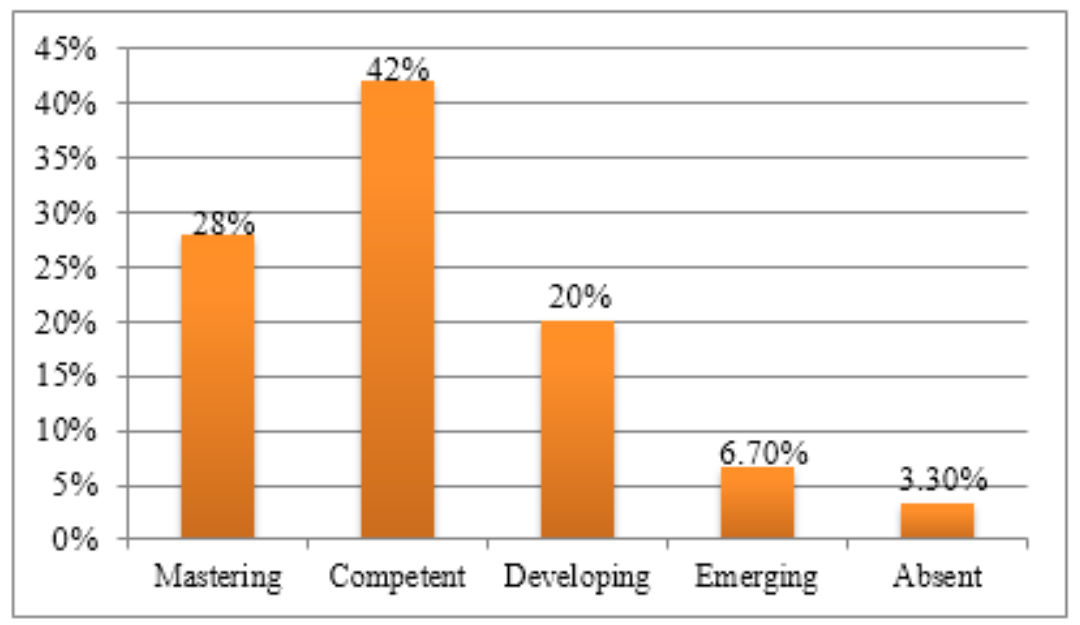

Figure 6. Students' Scientific Literacy Test Results

The test results showed that the majority of the students demonstrated a competent (42\%) or mastering (28\%) level of scientific literacy, while a small proportion of the students could not define alternative energy concepts correctly, even after in-depth explanations were provided. Most of the students demonstrated a good conceptual understanding of energy. They understood the process of making simple hand and solar power plants and could predict products formed from solar cells, coils, and magnets. The following is a discussion of the results of students' scientific literacy analysis in five categories by Shwartz, Ben-Zvi, and Hofstein (2006).

\subsubsection{General Scientific Ideas}

Aspects of general scientific ideas are aspects that measure students' ability to conduct scientific investigations, make generalizations of findings, and propose theories to explain natural phenomena and use knowledge to explain phenomena (Shwartz, Ben-Zvi, \& Hofstein, 2006). In this study, the development of general scientific idea skills in students is marked by the ability of students to discuss and analyze the source of problems, conduct scientific investigations, and overcome problems related to alternative energy, until they can make decisions with the guidance of the teacher. The STEAM-PjBL implementation stimulates students' curiosity to develop more deeply in order to build their scientific understanding.

"What are the alternatives that can be used as electricity generator?

The wind can be used as a power plant to turn on lights at home"

\section{(Interview of Student 1, 19 August 2019)}

"The copper coil used to produce this magnetic field is also found in fan, right? I've seen it, when I open the burning fan, it turns out the coil inside is burning"

\section{(Classroom Observation, 22 August 2019)}

The results of the above study indicate that students are able to carry out simple scientific investigations through the results of their observations of their experiences in daily life. In addition, the results of the study also indicate that students are able to solve problems through understanding the concept that wind can be used as a source of electricity generator. This is in line with the opinion of Ridwan, Rahmawati, Nurbaity, and Hadinugrahaningsih (2017) who revealed that transdisciplinary learning that is accompanied by an evaluation of students' scientific literacy in project-based learning can develop students' skills in solving problems that occur in students' daily lives.

\subsubsection{Science Characteristic}

Science characteristics were explored in topic of energy. Students who have good scientific literacy can understand that alternative energy knowledge is needed to explain, energy is something that can be assessed scientifically as usual in life. This knowledge is part of science learning delivered with the aim of providing an understanding of alternative energy phenomena (Shwartz et al., 2006)

"I can understand that energy will quickly run out if we use it continuously, so that energy needs to be renewed for the benefit of humans in everyday life"

(Reflective Journal of Student 26, 5 September 2019)

"It turned out that the electric shock is not dangerous because it has a weak power, even though I was very scared of electric shock, now I know that electric shock has a weak and high power"

(Reflective Journal of Student 14, 5 September 2019)

The results of the above study indicate that students already have an understanding of the characteristics of learning materials about energy, especially regarding the importance of making alternative energy as an energy renewal to meet human needs. In addition, students also have an understanding of energy characteristics related to electrical conductivity which are categorized in two stun power forces, high and low. This proves that the application of STEAM-PjBL in learning alternative energy is able to foster opportunities for the development of creativity and innovation to solve real problems by 
applying the concept of learning (Erba, 2019).

3.2.3. Science in Context

The development of aspects of science in context of energy learning is characterized by the ability of students to discover the relationship between energy knowledge and its use in everyday life.

"During my learning I learned the importance of electrical energy in daily life. I can also understand that magnets are used in electricity generation in petroleum power generators, magnets are also the driving energy for generators"

(Reflective Journal of Student 5, 18 September 2019)

"In my opinion, by making projects, learning alternative energy becomes fun because we get real experience" (Reflective Journal of Student 7, 10 September 2019)

"Used fans can also be used for alternative energy for hand power"

(Reflective Journal of Student 23, 19 September 2019)

Based on the data above shows that students already have the ability of scientific literacy in aspects of science in context properly, it means students have been able to see the relevance and usefulness of science, and use scientific knowledge to explain phenomena in everyday life. The application of STEAM-PjBL provides an opportunity for students to associate the concepts they learn with their daily lives that are characterized by the ability of students to explore components in the fan that can be used as components of a power plant project. This is in line with the contextual-based learning objectives of connecting learning with students' experiences in daily life and building new knowledge based on analysis and synthesis of students during the learning process (Hudson \& Whisler, 2013). This proves that STEAM-PjBL as contextual based learning can create meaningful learning (King, 2012).

\subsubsection{High-Order Thinking Skills}

High-order learning skills is an aspect of literacy that measure a person's ability to identify scientific issues, explain scientific phenomena, use scientific evidence, and evaluate the pros/ cons of debates (Shwartz, Ben-Zvi, \& Hofstein, 2006). In this study, the development of high-order learning skills is seen through the ability of students to question something and relate it to the information they receive to find the answer.

After students complete the project then present the results of the project. According to the teacher, the results of student presentations have been good even though sometimes elementary school students are still limited in delivering their presentations.

Teacher: What should be done to save energy in the future?

Student 8: There needs to be alternative energy at home such as solar panels as electricity generation when there is a power outage.

(Researcher Fieldnotes, 24 September 2019)
"In today's learning, some students have dared to ask various questions, student 7 asked their groups to decorate miniature power plant houses with car garages and student 8 also asked what if he made a large solar panel when he was an adult, because he was interested in alternative energy learning by using solar panels"

(Researcher Fieldnotes, 24 September 2019)

The results of the data above show the teacher can help students to build their own meaning and knowledge through students' metacognitive processes that are able to develop higher-order thinking skills (Rahmawati \& Ridwan, 2017). The reference mentioned that students can develop critical thinking skills by asking questions, defining problems, examining evidence, analyzing assumptions, and considering other interpretations (Wade, 1995). This finding is in line with research conducted by (Rahmawati, Ridwan, Hadinugrahaningsih, \& Soeprijanto, 2019) which shows that learning with the STEAM approach is able to develop students' critical thinking skills.

\subsubsection{Affective Aspect}

Affective Aspects are shown through how students show interest, curiosity, and enthusiasm for learning. In this study, students expressed excitement when successfully creating their projects. The students enjoyed experiencing first-hand what they had previously only read and seen in books, as shown by the following interview below.

"STEAM learning is very fun because it passes through various stages of discussion, making projects and the most exciting is making home creations, even though the results are less satisfying. However, it motivated me to try to be more perfect. I was very happy, it turned out that electricity could be created by me who was only an elementary school student, the materials used were easy to obtain and the instructions were easy to understand because the teacher explained it clearly. We learn through real practice, so that I can understand that energy is around us, we can use it, and we need to keep it from running out by making alternative energy"

(Interview of Student 10, 24 September 2019)

The interview results above show that the implementation of STEAM-PjBL gives a positive impression and provides a pleasant learning experience. In addition, students are also able to develop caring attitudes and responsibilities through project making activities. STEAM learning in a previous study conducted by Rikoon et. al. (2018) identified that motivation and perseverance in emotional skills have the potential to be fostered to increase achievement, motivation, and the ability to build cooperation between students. This is in line with research conducted by Steele and Ashworth (2018) stating that STEAM learning featuring humorous involvement and pleasure will expedite student construction projects. The whole program is designed as a whole in multidisciplinary integrated STEAM learning through the creation of 
creative products that have a positive impact on learning; this has an effect on student persistence in making products cognitive and affective domains of elementary school students (Choi \& Hong 2013). This is in line with research by Majid and Rohaeti (2018) which shows that contextual based learning is effective in developing positive attitudes of students.

\section{Conclusions}

The results of the study show that the STEAM-PjBL approach can be applied in elementary school level science learning to develop student scientific literacy. The results showed that the majority of students had reached the competent level. This indicates that students have been able to see the relevance of the importance of scientific knowledge to explain the phenomena they encounter in everyday life (science in context aspect). Analysis on general scientific ideas aspect shows that students' curiosity increases and students are able to make simple scientific investigations. In learning, students have dared to ask questions and have the ability to find relevant and credible information to obtain answers (high-order learning skills aspect). The application of STEAM-PJBL in science learning gives a positive impression on students so that learning becomes more meaningful, students have also been able to develop various positive attitudes such as tolerance, responsibility, and concern for others and the environment (affective aspect). The challenges faced by researchers during the research are source and time management, project ideas that are appropriate to the topic of learning and the cognitive level of students, as well as student involvement in learning. In addition, the integration of STEAM-PjBL into learning encourages teachers to be able to innovate in organizing creative learning so students can increase learning motivation, provide meaningful learning, and provide opportunities for students to develop their scientific literacy.

\section{Acknowledgments}

The authors thank Ministry of Education and Culture for Research Funding and SDN Aren Jaya XVIII Bekasi, West Java, Indonesia for the supports and collaboration.

\section{REFERENCES}

[1] Afriana, J., Permatasari, A., Fitriani, A. Penerapan Project Based Learning Terintegrasi STEM untuk Meningkatkan Literasi Sains Siswa ditinjau dari Gender, Jurnal Inovasi Pendidikan IPA, 202-212, 2016.

[2] Ajayi, V. O. Science and Society, Faculty of Education,
Benue State University, Makurdi, 2018.

[3] Bauer, J. R., Booth, A. E. Exploring potential cognitive foundations of scientific literacy in preschoolers: Causal reasoning and executive function, Early Childhood Research Quarterly, 46, 275-284, 2019.

[4] Buchholz, B. A., Pyles, D. G. Scientific Literacy in the Wild: Using Multimodal Texts in and out of School, Reading Teacher, 72(1), 61-70, 2018.

[5] Chen, Y. C. Using the Science Talk-Writing Heuristic to Build a New Era of Scientific Literacy, Reading Teacher, 73(1), 51-64, 2019.

[6] Chen, C. H., Yang, Y. C. Revisiting the effects of project-based learning on students' academic achievement: A meta-analysis investigating moderators, Educational Research Review, 26, 71-81, 2019.

[7] Choi, Y., Hong, S. H. The Development and Application Effects of STEAM Program About World of Small Organisms' Unit in Elementary Science, Elementary Science Education, 32 (3), 361- 377, 2013.

[8] Çoker, B., Çatlioğlu, H., Birgin, O. Conceptions of students about renewable energy sources: A need to teach based on contextual approaches, Procedia - Social and Behavioral Sciences, 2(2), 1488-1492, 2010.

[9] Davies, D., Jindal-Snape, D., Collier, C., Digby, R., Hay, P., Howe, A. Creative learning environments in education-A systematic literature review, Thinking Skills and Creativity, 8, 80-91, 2013.

[10] Erba, M. D. Policy Considerations for STEAM Education, Education Commision of the States, United States, 2019.

[11] Hudson, C. C., Whisler, V. R. Contextual Teaching and Learning for Practitioners, Systemics, Cybernetics, and Informatics, 54-58, 2013.

[12] King, D. New perspectives on context-based chemistry education: using a dialectical sociocultural approach to view teaching and learning, Studies in Science Education, $51-87,2012$.

[13] Laboy-Rush, D. Integrated STEM education through project-based learning, Portland, http://www.learning.com, 2010.

[14] Majid, A. N., Rohaeti, E. The Effect of Context-Based Chemistry Learning on Student Achievement and Attitude, American Journal on Educational Research, 836-839, 2018.

[15] Merritt, E. G. Bowers, N., Rimm-Kaufman, S. E. Making connections: Elementary students' ideas about electricity and energy resource, Renewable Energy, Elsevier, 138(C), 1078-1086, 2019.

[16] Miles \& Huberman. Qualitative Data Analysis: An Expanded Sourcebook, Sage Publication, Newyork, 1992.

[17] Murcia, K. Science for the 21st century: Teaching for scientific literacy in the primary classroom, Teaching Science, 1-16, 2007.

[18] National Research Council (NRC). A Framework for K-12 Science Education: Practices, Crosscutting Concepts, and Core Ideas, National Academies Press, Washington DC, 
2012.

[19] OECD. PISA 2018 Insights and Interpretations, OECD Publishing, Paris, 2019.

[20] Rahmawati, Y., Taylor, P. C. Moments of critical realisation and appreciation: a transformative chemistry teacher reflects, Reflective Practice, 16(1), 31-42, 2015.

[21] Rahmawati, Y., Ridwan, A. Empowering students' chemistry learning: The integration of ethnochemistry in culturally responsive teaching., Chemistry, 26(6), 813-830, 2017.

[22] Rahmawati Y., Ridwan A., Hadinugrahaningsih T., Soeprijanto. Developing critical and creative thinking skills through STEAM integration in chemistry learning, Journal of Physics: Conference Series, 1156, 1-7, 2019.

[23] Rais, M. Model Project Based-Learning sebagai Upaya Meningkatkan Prestasi Akademik Mahasiswa, Jurnal Pendidikan dan Pengajaran Undiksha, 43(3), 246-252, 2010.

[24] Ridwan, A., Rahmawati, Y., Hadinugrahaningsih, T. STEAM Integration in Chemistry Learning for Developing 21st Century Skills, MIER Journal of Educational Studies, Trends \& Practice, 7(2), 184 - 194, 2017.

[25] Ridwan A., Rahmawati, Y, Nurbaity, Hadinugrahaningsih, T. Integration of a Socio-Critical and Problem Oriented Approach in Chemistry Learning for students' Soft Skills Development, MIER Journal of Educational Studies, Trends \& Practice, 7(2), 33-41, 2017.

[26] Rikoon, S., Finn, B., Jackson, T., Inglese, P. Crosscutting Literature on STEAM Ecosystems, Expectancy Value Theory, and Social Emotional Learning: A Metadata Synthesis, ETS Research Report Series, 2018(1), 1-15, 2018.

[27] Roach, W. A. The Impact Oof Using Elementary Science Specialists on 5th Grade Science Achievement Scores, Liberty University, United States, 2018.

[28] Şahin, F., Özer, E., Deniz, M. E. The predictive level of emotional intelligence for the domain-specific creativity: A study on gifted students, Education and Science, 41, 181-197, 2016.

[29] Shwartz, Y., Ben-Zvi, R., Hofstein, A. The use of scientific literacy taxonomy for assessing the development of chemical literacy among high-school students, Chem. Educ. Res. Pract, 7(4), 203-225, 2006.

[30] Siagian, P., Silitonga, M., Djulia, E. Scientific Literacy Skills of Seventh Grade Junior High School (SMP Negeri) Students in North Labuhanbatu Regency, International Journal of Humanities Social Sciences and Education (IJHSSE), 4(11), 176-182, 2017.

[31] Steele, A., Ashworth, E. L. Emotionality and STEAM Integrations in Teacher Education, Journal of Teaching and Learning, 11(2), 11-25, 2018.

[32] Taylor, P. C. Why is a STEAM curriculum perspective crucial to the 21 st century? Australian Curriculum: Science, 89-93, 2016.

[33] UNESCO. Towards knowledge societies UNESCO World Report, UNESCO, Paris, 2005.
[34] Vossen, T., Henze, I., Rippe, R. C. A., Van Driel, J. H., De Vries, M. J. Attitudes of Secondary School STEM Teachers towards Supervising Research and Design Activities, Research in Science Education, 1-21, 2019.

[35] Wade, C. Using Writing to Develop and Assess Critical Thinking, Teaching of Psychology, 24-28, 1995.

[36] Yamamoto, E., \& Houghton, M. Energy Conservation Learning Activities, Ontario EcoSchool, Toronto, 2011.

[37] Yüksel, Y. E. Elementary science teacher candidates' views on hydrogen as future energy carrier, International Journal of Hydrogen Energy, 44(20), 9817-9822, 2019. 